\title{
PENGARUH MEDIA PEMBELAJARAN VISUAL TIGA DIMENSI (SKETCH UP) TERHADAP HASIL BELAJAR SISWA PADA MATERI PELAJARAN MACAM- MACAM PEKERJAAN KONSTRUKSI KAYU
}

\author{
Rirky Ramadhan ${ }^{1}$, Arris Maulana², Doddy Rochadi ${ }^{3}$ \\ ${ }^{1}$ Alumni PTB FT UNJ, ramadhan.civic@gmail.com \\ ${ }^{2}$ Dosen PTB FT UNJ, arrismaulana@,uni.ac.id \\ ${ }^{3}$ Dosen PTB FT UNJ, drohadi@unj.ac.id
}

\begin{abstract}
Abstrak
Penelitian ini bertujuan untuk mengetahui pengaruh media visual tiga dimensi terhadap hasil belajar siswa pada materi macam-macam pekerjaan konstruksi kayu siswa SMKN 56 Jakarta kompetensi keahlian teknik gambar bangunan kelas X dan media pembelajaran visual tiga dimensi membantu siswa dalam memahami materi macam-macam pekerjaan konstruksi kayu dalam mata pelajaran konstruksi bangunan.

Penelitian ini menggunakan teknik analisis kuantitatif dengan menggunakan metode quasi eksperimen. Sampel dalam penelitian ini adalah siswa kelas X Teknik Gambar Bangunan yang berjumlah 56 siswa yang dibagi kedalam 2 kelompok kelas, yaitu kelas kontrol (kelas yang menggunakan media powerpoint) dengan jumlah 28 siswa dan kelas eksperimen (kelas yang menggunakan media visual tiga dimensi) yang berjumlah 28 siswa. Analisis data digunakan uji - $t$ dua pihak sampel independen.

Hasil belajar sebelum dilakukan pembelajaran macam-macam pekerjaan konstruksi kayu menunjukkan bahwa hasil belajar kelas kontrol memiliki nilai 45-95 dengan rata-rata 73,03. Hasil belajar kelas eksperimen memiliki nilai 50-95 dengan rata-rata 71,96. Sedangkan hasil belajar setelah dilakukan pembelajaran macam-macam pekerjaan konstruksi kayu menunjukkan bahwa hasil belajar kelas kontrol memiliki nilai 50-95 dengan rata-rata 75,17. Hasil belajar kelas eksperimen memiliki nilai 65-95 dengan rata-rata 85,17. Hasil data yang didapat kemudian diolah dengan uji $-\mathrm{t}$ yang menghasilkan nilai $\mathrm{t}_{\text {hitung }}=3,595$ dan $\mathrm{t}_{\text {tabel }}=2,056$, sehingga dapat disimpulkan bahwa niai $t_{\text {hitung }} \geq t_{\text {tabel }}$ atau 3,595 $>2,056$ yang berarti terdapat perbedaan hasil belajar yang signifikan antara kelas kontrol dan kelas eksperimen. Maka dapat disimpulkan media pembelajaran visual tiga mempengaruhi hasil belajar materi macam-macam pekerjaan kontruksi kayu kelas X di SMK Negeri 56 Jakarta.
\end{abstract}

Kata Kunci : Media Visual Tiga Dimensi, Macam-Macam Pekerjaan Konstruksi kayu, Hasil Belajar. 


\title{
EFFECT OF THREE DIMENSION VISUAL LEARNING MEDIA (SKETCH UP) ON STUDENT LEARNING RESULT IN LEARNING MATERIALS TYPE OF WOOD CONSTRUCTION WORK
}

\author{
Rizky Ramadhan ${ }^{1}$, Arris Maulana², Doddy Rochadi ${ }^{3}$ \\ ${ }^{1}$ Alumni PTB FT UNJ, ramadhan.civio@gmail.com \\ ${ }^{2}$ Lecturer of PTB FT UNJ, arrismaulana@,unj.ac.id \\ ${ }^{3}$ Lecturer of PTB FT UNJ, drohadi@unj.ac.id
}

\begin{abstract}
This study aims to know the correlation between three-dimentional media to learning outcomes on subject types of wood construction of students at SMKN 56 Jakarta in competency skills of Drawing Building Engineering 10th grade and The three-dimensional visual learning media assist students in understanding the subject types of wood construction.

Data analysis technique that using is quantitative technique with quasi experiment method.

The sample of this study is 10 grade students of Drawing Building Engineering which amounts to 56 students and divided into to 2 classes, that is control class (the class that using conventional media) with 28 students and experimental class (the class that using three-dimentional media) which amounts to 28 students. The data analysis used two independent samples $t$ - test..

The learning outcomes before learning of types of wood construction shows that the control class is between 45-95 with average 73,03. The learning outcomes of experimental class is between 50-95 with average 71,96. Meanwbile the learning outcomes after learning types of wood construction shows that the control class between 50-95 with average 75,17 and the experimental class is between 65-95 with average 85,17. Then the result be treated with $T$-test discovered $t_{\text {calculate }}=3,595$ and $t_{\text {table }}=2,056$, so can be concluded that the $t_{\text {calculate }} \geq$ $t_{\text {table }}$ or 3,595 > 2,056 which means there is different between control class and experimental class.. So we can conclude three-dimentional media development more effectively used in the learning process class X SMK Negeri 56 Jakarta.
\end{abstract}

Keywords: Three-dimentional Media, Types of Wood Construction, Learning Outcomes.

\section{Pendahuluan}

Salah satu tujuan khusus pendidikan kejuruan berdasarkan Undang-Undang Republik Indonesia No.20 tahun 2003 tentang Sistem Pendidikan Nasional pasal 15 adalah untuk menyiapkan siswa agar dapat bekerja, baik secara mandiri atau mengisi lapangan pekerjaan yang ada di dunia usaha dan industri sebagai tenaga kerja tingkat menengah, sesuai dengan bidang dan program keahlian yang diminati. SMKN 56 pada kompetensi keahlian Teknik Gambar Bangunan kelas X terdapat mata pelajaran konstruksi bangunan. Sesuai silabus mata pelajaran konstruksi bangunan ini terdiri dari berbagai macam kompetensi dasar diantaranya kompetensi dasar macammacam pekerjaan konstruksi kayu, kompetensi dasar tersebut memiliki indikator bahwa siswa memahami materi macam-macam pekerjaan konstruksi kayu dan diharapkan mampu untuk membayangkan kondisi riil dari materi yang disampaikan oleh guru. Oleh karena itu diperlukan suatu visualisasi yang hampir menyerupai bentuk aslinya untuk dapat dipahami dengan baik.

Kegiatan pembelajaran yang berlangsung di SMK Negeri 56 Jakarta telah berkembang sesuai dengan tuntutan kurikulum yang saat ini telah diterapkan, yaitu Kurikulum 2013 (Kurtilas) yang menuntut guru untuk lebih kreatif dan inovatif dalam melakukan kegiatan pembelajaran. Namun dalam kenyataanya sebagian guru pada saat ini masih 
menggunakan metode konvensional (ceramah) dengan secara utuh dalam menyampaikan materi pembelajarannya, biasanya mereka hanya menggunakan media power point secara terus menerus. Kondisi seperti ini menjadikan siswa kurang antusias atau kurang bersemangat, dan terlihat acuh tak acuh dengan apa yang disampaikan oleh guru tersebut, akibatnya hasil belajar mereka kurang baik dan menjadikan mereka kurang berkompeten dalam dunia kerja sehingga berimbas kurang maksimalnya pencapaian tujuan dari Sekolah Menengah Kejuruan (SMK) itu sendiri.

Pada era modern sekarang ini, dunia pendidikan banyak memanfaatkan Information Technology (IT) dalam segala aspeknya tidak terkecuali pada aspek pembelajaran di kelas, salah satu pemanfaatan IT adalah pemanfaatan komputer. Guru di SMK Negeri 56 Jakarta sudah difasilitasi komputer atau laptop, tetapi pada kenyataanya guru-guru hanya menggunakan power point dengan metode ceramah.

Power point adalah sebuah program presentasi yang digunakan untuk memperkenalkan atau menjelaskan sesuatu melalui tampilan slide. Kelemahan menggunakan media power point dalam proses pembelajaran dengan metode ceramah ini adalah pembelajaran masih berpusat pada guru. Selain itu penggunaan media power point dalam jangka panjang akan terasa membosankan bagi siswa karena terlalu sederhana dan kurang menarik yang selanjutnya berakibat pada hasil belajar siswa pada kelas tersebut kurang maksimal untuk meningkatkan hasil belajar.

Sebagai bukti hal tersebut dapat dilihat dari data hasil observasi awal yang dilakukan penulis pada saat Praktik Keterampilan Mengajar (PKM) bulan Agustus 2016 di SMKN 56 Jakarta yang menunjukkan bahwa nilai hasil belajar pada kelas X TGB tahun ajaran 2016/2017 pada materi macam-macam pekerjaan konstruksi kayu dari 56 siswa terdapat 40 siswa yang telah memenuhi kriteria ketuntasan minimal (KKM), sedangkan 16 siswa lainnya belum memenuhi KKM. Bagi guru mata pelajaran hal ini dirasa kurang memuaskan mengingat guru menginginkan seluruh siswa memenuhi Kriteria Ketuntasan Minimum (KKM) yang ditetapkan disekolah yaitu 75 . Melalui pemilihan media yang tepat diharapkan dapat mempermudah siswa dalam memahami materi pelajaran yang diberikan sehingga siswa dapat mencapai kompetensi yang telah ditetapkan.

Salah satu media pembelajaran dengan pemanfaatan Informasi Technology (IT) yang dapat diaplikasikan pada mata pelajaran konstruksi bangunan dengan materi macam-macam pekerjaan konstruksi kayu adalah menggunakan media pembelajaran visual tiga dimensi. Dalam penelitian ini peneliti menggunaan software Google Sketch Up 2015 untuk membuat gambar tiga dimensi yang dibuat sesuai dengan kondisi yang kenyataanya ada di lapangan. Software Sketch Up digunakan karena lebih mudah pengoperasiannya dan hasil gambar yang ditampilan juga cukup baik untuk keperluan presentasi.

Menurut Sudjana dan Rivai (2002:9) "pengajaran akan lebih efektif apabila objek dan kejadian yang menjadi bahan pengajaran dapat divisualisasikan secara realistik atau menyerupai keadaaan yang sebenarnya, namun tidaklah berarti bahwa media harus selalu menyerupai keadaan yang sebenarnya". Sejalan dengan pedapat ahli yang telah dijelaskan penggunaan media pembelajaran visualisasi tiga dimensi (SketchUp) pada mata pelajaran Konstruksi bangunan dengan materi macam-macam pekerjaan konstruksi kayu diharapkan membantu membuat rangsangan dan ketertarikan terhadap siswa dapat membantu untuk memahami secara utuh serta mampu membayangkan kondisi yang sebenarnya dari materi yang disampaikan oleh guru. Sehingga diharapkan nantinya ada peningkatan hasil belajar siswa lebih baik dari pada sebelumnya. 


\section{Identifikasi masalah}

Berdasarkan uraian latar belakang di atas, maka masalah yang teridentifikasi adalah sebagai berikut :

1. Bagaimana mengoptimalkan media dalam pembelajaran konstruksi bangunan kelas X di SMK Negeri 56 Jakarta?

2. Bagaimana ketuntasan nilai sesuai KKM (Kriteria Ketuntasan Minimal) yang ada di SMKN 56 Jakarta?

3. Bagaimana pengaruh media pembelajaran visual tiga dimensi (Sketch Up) terhadap hasil belajar siswa pada materi macam-macam konstruksi kayu kompetensi keahlian teknik gambar bangunan di SMK Negeri 56 Jakarta?

\section{Pembatasan Masalah}

Batasan masalah digunakan peneliti dalam penelitiaan ini untuk membatasi dan memfokuskan penelitian maka peneliti membatasi masalah hanya pada:

1. Kompetensi dasar pada silabus yang akan dibahas dalam penelitian adalah KD 3.9 dengan materi macam-macam pekerjaan konstruksi kayu.

2. Pengukuran hasil belajar hanya pada kemampuan dimensi kognitif.

3. Media pembelajaran yang digunakan adalah media visual tiga dimensi dengan program Sketch Up 2015.

4. Identifikasi masalah yang dipilih adalah pengaruh media pembelajaran visual tiga dimensi (Sketch Up) terhadap hasil belajar siswa pada materi macammacam konstruksi kayu kompetensi keahlian teknik gambar bangunan di SMK Negeri 56 Jakarta.

\section{Perumusan Masalah}

Adanya permasalahan yang jelas dalam suatu penelitian akan menjadikan proses pemecahannya dapat terarah dan terfokus. Berdasarkan latar belakang diatas, maka terindentifikasi suatu perumusan masalah, yaitu : Bagaimana pengaruh penggunaan media pembelajaran visual tiga dimensi terhadap hasil belajar siswa pada materi macam-macam pekerjaan konstruksi kayu kompetensi keahlian teknik gambar bangunan di SMKN 56 Jakarta?

\section{Manfaat Penelitian}

Manfaat praktis yang dapat diambil dari penelitian ini, yaitu:

1. Dapat mempermudah pemahaman siswa mengenai materi mata pelajaran konstruksi bangunan dengan materi macam-macam pekerjaan konstruksi kayu.

2. Dapat membantu siswa untuk mampu memvisualisasikan hal-hal yang masih abstrak dalam materi mata pelajaran konstruksi bangunan gedung dengan materi macam-macam pekerjaan konstruksi kayu.

3. Menjadi perangkat bantu dan alternatif dalam pembelajaran konstruksi bangunan dengan materi macammacam pekerjaan konstruksi kayu.

4. Diharapkan dapat digunakan sebagai bahan acuan pengembangan media pembelajaran guna meminimalisasi kejenuhan dan kebosanan dalam pembelajaran konvensional di dalam kelas yang mengakibatkan motivasi belajar siswa menjadi berkurang untuk memahami materi yang diberikan oleh guru.

\section{Tujuan Penelitian}

Adapun tujuan penelitian ini adalah

1. Untuk mengetahui pengaruh media pembelajaran visual tiga dimensi (Sketch Up) terhadap hasil belajar siswa kelas $\mathrm{X}$ TGB 1 dan 2 SMKN 56 Jakarta.

2. Media pembelajaran visual tiga dimensi dapat membantu siswa dalam memahami materi macam-macam pekerjaan konstruksi kayu dalam mata pelajaran konstruksi bangunan. 


\section{Tinjauan Pustaka}

Slameto (2013:2) mendefinisikan belajar sebagai suatu proses usaha yang dilakukan seseorang untuk memperoleh suatu perubahan tingkah laku yang baru secara keseluruhan, sebagai hasil pengalamannya sendiri dalam interaksi dengan lingkungan. Lebih lanjut Siregar dan Nara (2014:5) mendefinisikan belajar merupakan suatu aktivitas mental (psikis) yang berlangsung dalam interaksi dengan lingkungannya yang menghasilkan perubahan yang bersifat relatif konstan. Berdasarkan pendapat tersebut dapat disimpulkan bahwa belajar adalah sebuah usaha yang bertujuan untuk menghasilkan perubahan yang bersifat menetap sebagai hasil dari (aktivitas) pengalaman di lingkungan.

Mata pelajaran konstruksi bangunan diajarkan untuk siswa kelas $\mathrm{X}$ kompetensi keahlian teknik gambar bangunan. Dalam penelitian ini kompetensi dasar yang dibahas adalah KD 3.9 mengkategorikan macam-macam pekerjaan kontruksi kayu. Alasan peneliti memilih kompetensi dasar tersebut adalah media pembelajaran visual dimensi yang digunakan penulis dirasa sangat efektif untuk menerjemahkan gambar-gambar dua dimensi pada buku rujukan konstruksi bangunan menjadi tiga dimensi pada materi macam-macam pekerjaan konstruksi kayu. Karena pada materi itu terdapat beragam bahasan sambungan kayu seperti, sambungan bibir, sambungan takikan dll. yang akan sangat jelas penggunaannya dilapangan jika ditampilkan secara tiga dimensi. Untuk kompetensi dasar lain yang terdapat materi batu, beton, genting, keramik dll. dirasa agak kurang efektif jika menggunakan media pembelajaran visual tiga dimensi.

Menurut Bovee dalam Ouda Teda Ena (2001: 2) "Media adalah sebuah alat yang mempunyai fungsi menyampaikan pesan". Media merupakan wadah dari pesan yang oleh sumber pesan ataupun penyalurnya ingin diteruskan kepada sasaran atau penerima pesan tersebut. Menurut Arsyad (2002: 12) "Media pembelajaran adalah sebuah alat yang berfungsi untuk menyampaikan pesan pembelajaran". Media pembelajaran merupakan salah satu komponen pendukung keberhasilan proses belajar mengajar. Menurut Undang-Undang Republik Indonesia No.20 Tahun 2003 Pasal 1 ayat 20: "Pembelajaran adalah proses interaksi peserta didik dengan pendidik dan sumber belajar pada suatu lingkungan belajar".

Kemp \& Dayton dalam Azhar Arsyad, (2002:21), mengelompokkan media ke dalam delapan jenis : (a) media cetakan, (b) media pajang, (c) Overhead Transparacies, (d) rekaman audiotape, (e) seri slide dan filmstrips, (f) penyjian multi-image, (g) rekaman video dan film hidup, dan (h) komputer. Kemudian Basuki Wibawa \& Farida Mukti, (1992:24), mengklarifikasikan media pengajaran dalam empat jenis yaitu : (a) media audio, (b) media visual (visual diam dan visual gerak), (c) media audio visual, dan (d) media serbaneka.

Penyampain materi dengan menggunakan media pembelajaran dianggap penting karena media pembelajaran disini dapat membantu menstimulus indera dari pesarta didik. Menurut Kemp dan Dayton dalam Arsyad (2002:22), dalam pengembangan sufmber belajar, media pembelajaran memiliki manfaat yaitu:

1. Penyampaian materi pelajaran lebih baku.

2. Pengajaran bisa lebih menarik.

3. Pembelajaran menjadi lebih interaktif.

4. Lama waktu pengajaran dapat dipersingkat.

5. Kualitas hasil belajar dapat ditingkatkan.

6. Pengajaran dapat diberikan kadan dan dimana saja diinginkan maupun diperlukan.

7. Sikap positif siswa terhadap apa yang mereka pelajari dan terhadap proses belajar dapat ditingkatkan.

8. Peran guru dapat berubah kearah yang lebih positif. 
Pengertian Google SketchUp adalah sebuah program grafis. Program ini memberikan hasil utama yang berupa gambar sketsa grafik tiga dimensi. Perangkat lunak ini sangat tepat digunakan untuk membuat atau mendesain objek tiga dimensi dengan perbandingan panjang, lebar, maupun tinggi. Pengeditannya lebih mudah dibandingkan bila menggunakan perangkat lunak grafis lain. SketchUp juga memiliki kelebihan pada kemudahan penggunaan dan kecepatan dalam melakukan desain, serta menyenangkan berbeda dengan program $3 D$ lainnya.

Menurut Daryanto (2010:63) Microsoft power point merupakan sebuah software yang dibuat dan dikembangkan oleh perusahaan microsoft, dan merupakan salah satu program berbasis multimedia. Program ini dirancang khusus untuk menyampaikan presentasi dengan berbagai fitur menu yang mampu menjadukannya sebagai media yang menarik. Sedangkan menurut Susilana (2007:99) Microsoft power point merupakan program aplikasi persentasi dalam komputer. Sebagai program aplikasi presentasi yang populer, microsoft power point paling banyak digunakan untuk berbagai kepentingan persentasi, baik persentasi produk, meeting, seminar, lokakarya, dan dalam pembelajaran. Dengan menggunakan power point, kita dapat membuat persentasi secara professional danbahkan jika perlu hasil persentasi dapat ditempatkan di server web untuk diakses sebagai bahan pembelajaran atau informasi yang lainnya. Selain penggunaannya mudah, program power point dapat diintegrasikan dengan microsoft yang lainnya seperti word, excel, access dan sebagainya.

\section{Metode Penelitian}

Metode yang digunakan dalam penelitian ini adalah metode quasi eksperimen dengan non-equivalent control group design. Menurut Sugiyono (2009:116) "Non-equivalent control grup design hampir sama dengan pretest-post test control grup design, hanya pada desain ini kelompok eksperimen maupun kelompok kontrol tidak dipilih secara random"

Tabel 1. Kelompok Kontrol

\begin{tabular}{lccc}
\hline Kelompok & $\begin{array}{c}\text { Pre- } \\
\text { test }\end{array}$ & Perilaku & $\begin{array}{c}\text { Post- } \\
\text { test }\end{array}$ \\
\hline Eksperimen & $\mathrm{O}_{1}$ & $\mathrm{X}_{1}$ & $\mathrm{O}_{2}$ \\
Kontrol & $\mathrm{O}_{1}$ & $\mathrm{X}_{2}$ & $\mathrm{O}_{2}$ \\
\hline
\end{tabular}

\section{Hasil Penelitian dan Pembahasan}

\section{Hasil Belajar Kelompok Pretest}

Berikut ini adalah tabel nilai besertadistribusi frekuensi dan histogram pretest siswa pada kelas kontrol yaitu kelas yang menggunakan media konvensional dan kelas eksperimen yaitu kelas yang menggunakan media visua tiga dimensi.

Tabel 2. Data Nilai Peserta

\begin{tabular}{cccccc}
\hline No & Kont. & Eks. & No & Kont. & Eks. \\
\hline $\mathbf{1}$ & 80 & 90 & 15 & 95 & 65 \\
$\mathbf{2}$ & 80 & 80 & 16 & 80 & 50 \\
$\mathbf{3}$ & 80 & 95 & 17 & 90 & 65 \\
$\mathbf{4}$ & 85 & 60 & 18 & 80 & 55 \\
$\mathbf{5}$ & 45 & 55 & 19 & 50 & 50 \\
$\mathbf{6}$ & 90 & 70 & 20 & 70 & 70 \\
$\mathbf{7}$ & 65 & 85 & 21 & 70 & 90 \\
$\mathbf{8}$ & 65 & 65 & 22 & 55 & 60 \\
$\mathbf{9}$ & 70 & 85 & 23 & 50 & 65 \\
$\mathbf{1 0}$ & 80 & 65 & 24 & 90 & 90 \\
$\mathbf{1 1}$ & 85 & 90 & 25 & 90 & 60 \\
$\mathbf{1 2}$ & 70 & 75 & 26 & 55 & 70 \\
$\mathbf{1 3}$ & 80 & 85 & 27 & 65 & 80 \\
$\mathbf{1 4}$ & 75 & 70 & 28 & 55 & 75 \\
\hline & Jumlah & 2045 & 2015 \\
\hline & Mean & 73 & 71,9 \\
\hline
\end{tabular}




\begin{tabular}{ccc}
\hline Median & 77,5 & 70 \\
\hline Modus & 80 & 65 \\
\hline
\end{tabular}

Tabel diatas menunjukkan data nilai pretest pada kelas kontrol memiliki nilai maksimum sebesar 95 dan nilai terendahnya sebesar 45 dengan median 77,5 dan modus 80. Nilai maksimum untuk kelas eksperimen sebesar 95 dan nilai terendahnya sebesar 55 dengan median 70 dan modus 65. Rata-rata nilai untuk kelas kontrol sebesar 73,035 dan kelas eksperimen 71,964.

\section{Hasil Belajar Kelompok Posttest}

Tabel nilai beserta distribusi frekuensi dan histogram posttest siswa pada kelas kontrol yaitu kelas yang menggunakan media konvensional dan kelas eksperimen yaitu kelas yang menggunakan media visua tiga dimensi.

Tabel 3, Data Nilai Kelas Kontrol

\begin{tabular}{llllll}
\hline $\mathbf{1}$ & 85 & 95 & 15 & 95 & 85 \\
$\mathbf{2}$ & 80 & 90 & 16 & 80 & 85 \\
$\mathbf{3}$ & 85 & 95 & 17 & 80 & 85 \\
$\mathbf{4}$ & 95 & 65 & 18 & 70 & 80 \\
$\mathbf{5}$ & 50 & 70 & 19 & 60 & 85 \\
$\mathbf{6}$ & 95 & 80 & 20 & 70 & 85 \\
$\mathbf{7}$ & 60 & 80 & 21 & 80 & 95 \\
$\mathbf{8}$ & 70 & 80 & 22 & 60 & 70 \\
$\mathbf{9}$ & 80 & 95 & 23 & 50 & 85 \\
$\mathbf{1 0}$ & 70 & 85 & 24 & 85 & 95 \\
$\mathbf{1 1}$ & 85 & 95 & 25 & 85 & 85 \\
$\mathbf{1 2}$ & 75 & 85 & 26 & 70 & 85 \\
$\mathbf{1 3}$ & 80 & 85 & 27 & 80 & 85 \\
$\mathbf{1 4}$ & 70 & 95 & 28 & 60 & 85 \\
\hline
\end{tabular}

$\begin{array}{ccc}\text { Jumlah } & 2150 & 2385 \\ \text { Mean } & 75,17 & 85,17 \\ \text { Median } & 80 & 85 \\ \text { Modus } & 80 & 85\end{array}$

Tabel diatas menunjukkan data nilai posttest pada kelas kontrol memiliki nilai maksimum sebesar 95 dan nilai terendahnya sebesar 50 dengan median 80 dan modus 80. Nilai maksimum untuk kelas eksperimen sebesar 95 dan nilai terendahnya sebesar 65 dengan median 85 dan modus 85 . Rata-rata nilai untuk kelas kontrol sebesar 75,178 dan kelas eksperimen 85,178.

Perhitungan nilai yang telah dilakukan dapat terlihat bahwa peningkatan lebih banyak terhadap kelas eksperimen (kelas yang menggunakan media visual tiga dimensi) yaitu sekitar 15,51\% dengan selisih nilai rata-rata sebesar 12,142 dibanding dengan kelas kontrol (kelas yang menggunakan media powerpoint) yaitu 2,85\% dengan selisih nilai rata-rata sebesar 3,214.

Berdasarkan hasil perhitungan yang telah dilakukan didapat nilai $t_{\text {hitung }}=3,595$ dan $\mathrm{t}_{\text {tabel }}=2,056$ yang didapat dari df 26 dengan taraf kesalahan 5\%. Maka dapat disimpulkan bahwa nilai $t_{\text {hitung }}>t_{\text {tabel }}$ atau $3,595>2,056$, dengan demikian hal tersebut menunjukkan bahwa terdapat perbedaan rata-rata hasil belajar antara kelas eksperimen dan kelas kontrol.

Berdasarkan hasil analisis tahap akhir untuk uji peningkatan hasil belajar siswa (uji gain) diperoleh peningkatan hasil belajar siswa pada kelas eksperimen setelah mendapatkan perlakuan sebesar 0,55 dan masuk ke kriteria peningkatan hasil belajar siswa sedang. Peningkatan hasil belajar siswa pada kelas kontrol setelah mendapatkan perlakuan sebesar $0,16 \%$ dan masuk ke kriteria peningkatan hasil belajar siswa rendah. Sehingga dapat disimpulkan bahwa peningkatan hasil belajar siswa pada kelas 
eksperimen lebih tinggi jika dibandingkan dengan kelas kontrol.

Tabel 4. Rata-Rata Penilaian

\begin{tabular}{|c|c|c|c|}
\hline \multicolumn{2}{|c|}{ Nlai } & $\begin{array}{c}\text { Kelas } \\
\text { Kontrol }\end{array}$ & $\begin{array}{c}\text { Kelas } \\
\text { Eksperimen }\end{array}$ \\
\hline \multirow{2}{*}{ Pretest } & Tertinggi & 95 & 95 \\
\cline { 2 - 4 } & Terendah & 45 & 50 \\
\hline \multicolumn{2}{|c|}{ Rata-rata } & 73,03 & 71,96 \\
\hline \multirow{2}{*}{ Posttest } & Tertinggi & 95 & 95 \\
\cline { 2 - 4 } & Terendah & 50 & 65 \\
\hline \multicolumn{2}{|c|}{ Rata-rata } & 75,17 & 85,17 \\
\hline \multicolumn{2}{|c|}{$\begin{array}{c}\text { Presentase } \\
\text { Peningkatan (g) }\end{array}$} & $16 \%$ & $55 \%$ \\
\hline
\end{tabular}

Pembelajaran yang dikembangkan dengan media pembelajaran visual tiga dimensi SketchUp di kelas eksperimen adalah keaktifan siswa dalam membangun sendiri keingintahuannya. Hal ini disebabkan penggunaan media yang mudah ketika digunakan di laptop siswa masingmasing. Siswa dapat mengeksplor objek belajarnya secara mandiri. Dengan demikian, keaktifan siswa dalam membangun sendiri pengetahuannya diharapkan dapat membantu siswa untuk lebih lama mengingat dan memahami materi pelajaran macam-macam pekerjaan konstruksi kayu.

Berdasarkan hasil belajar siswa antara kelas yang menggunakan media powerpoint (kelas kontrol) dengan kelas yang menggunakan media visual tiga dimensi (kelas eksperimen) terdapat perbedaan hasil belajar siswa yang menggunakan media pembelajaran visual tiga dimensi dengan yang tidak menggunakan media pembelajaran visual tiga dimensi. Hasil belajar kelompok eksperimen dengan menggunakan media pembelajaran visual tiga dimensi menunjukkan hasil belajar lebih tinggi dibandingkan dengan yang tidak menggunakan media visual tiga dimensi.

\section{Keterbatasan Penelitian}

Penelitian yang dilakukan penulis sudah dilaksanakan dengan optimal untuk mengetahui hasil pencapaian akhir penelitian yang diharapkan, namun demikian penulis menyadari dalam penelitian ini ada suatu keterbatasan yang sulit dihindari, adapun keterbatasan dari penelitian ini antara lain :

1. Penelitian ini hanya mengambil 1 dari 12 Kompetensi Dasar (KD) dan dilakukan hanya dalam waktu singkat, sehingga dibutuhkan penelitian berkelanjutan untuk benar-benar mengetahui dampak penggunaan media pembelajaran sketch up yang akan diteliti.

2. Media visual tiga dimensi yang dibuat penulis ini masih jauh dari kata sempurna dan harus diperbaiki lagi sehingga pada penyampaian materi tidak mengalami hambatan.

3. Penerapan media pembelajaran dilakukan oleh Penulis sendiri yang mana penulis tidak memiliki kompetensi yang sama seperti guru di SMKN 56 Jakarta. Oleh karena itu, diperlukan guru yang berkompeten untuk menyampaikan materi dengan media visual tiga dimensi ini sehingga tujuan pembelajaran dapat tercapai.

\section{Kesimpulan}

Berdasarkan hasil penelitian dan pembahasan, dapat ditarik kesimpulan serbagai berikut:

1. Media pembelajaran sketch up pada proses pembelajaran kelas eksperimen memberikan dampak diantaranya lebih tertarik pada media yang digunakan, lebih fokus dalam pembelajaran dan memiliki minat belajar lebih baik. Hal ini dapat dilihat dari hasil belajar kelas eksperimen mempunyai nilai rata sebesar 85,17 , sedangkan hasil belajar siswa pada kelas kontrol mempunyai nilai rata-rata sebesar 75, 17.

2. Terdapat perbedaan yang signifikan terhadap hasil belajar siswa pada kelas eksperimen dan kelas kontrol dengan adanya peningkatan hasil belajar siswa pada kelas eksperimen sebesar 0,55 atau $55 \%$ termasuk kriteria sedang, dan hasil 
belajar pada kelas kontrol hanya mengalami peningkatan sebesar 0,16 atau 16\%. Maka dapat disimpulkan bahwa terdapat pengaruh penggunaan media sketch up materi macam-macam pekerjaan konstruksi kayu untuk mata pelajaran konstruksi bangunan terhadap hasil belajar pada siswa kelas X TGB SMKN 56 Jakarta.

\section{Saran}

Berdasarkan pengamatan peneliti selama melaksanakan penelitian eksperimen pada kelas X kompetensi keahlian Teknik Gambar Bangunan SMK Negeri 56 Jakarta, peneliti memberikan saran sebagai berikut :

1. Media pembelajaran visual tiga dimensi dengan SketchUp perlu digunakan oleh guru karena terbukti dapat meningkatkan hasil belajar siswa.

2. Perlu adanya pengembangan mengenai media pembelajaran yang digunakan dalam kegiatan penyampaian materi pelajaran oleh guru atau pengajar di dalam kelas, salah satunya adalah dengan menggunakan media pembelajaran visual tiga dimensi SketchUp pada mata pelajaran konstruksi bangunan materi macammacam pekerjaan konstruksi kayu atau mata pelajaran yang lain yang mempunyai karakteristik yang sama.

\section{Daftar Pustaka:}

Daryanto. 2010. Panduan Pembelajaran Kreatif dan Inovatif. Publisher: Jakarta. .

Republik Indonesia. 2003. Undang-undang Republik Indonesia Nomor 20 Tabun 2003 tentang Sistem Pendidikan Nasional. Sekretariat Negara. Jakarta

Siregar, E \& Nara, H. 2014. Teori Belajar dan Pembelajaran. Bogor: Ghalia Indonesia.

Slameto. 2013. Belajar dan Faktor-faktor yang Mempengarubinya. Jakarta: Rineka Cipta.

Sudjana. 2005. Metoda Statistika. Bandung: PT Tarsito Sudjana dan Rivai. (2002). Media Pendidikan. Jakarta: Balai Pustaka.
Sugiyono. 2009. Metode Penelitian Pendidikan Pendekatan Kuantitatif, Kualitatif, dan R\&D. Bandung: Alfabeta

Susilana, Rudi \& Riyana, Cepi. 2007. Media Pembelajaran. Bandung: CV Wacana Prima.

Wibawa, Basuki dan Mukti, Farida.1992. Media Pengajaran. Jakarta: DEPDIKBUD 
Jurnal Pendidikan Teknik Sipil 